\title{
Two new species of Acanthobothrium Blanchard, 1848 (Cestoda: Onchoproteocephalidea) from rajiform batoids off Argentina
}

\author{
Sebastián Franzese ${ }^{1,2}$ and Verónica A. Ivanov ${ }^{1,2, \uparrow}$ \\ ${ }^{1}$ Universidad de Buenos Aires, Facultad de Ciencias Exactas y Naturales, Departamento de Biodiversidad y Biología Experimental, \\ Buenos Aires, Argentina; \\ ${ }^{2}$ CONICET - Universidad de Buenos Aires, Instituto de Biodiversidad y Biología Experimental y Aplicada (IBBEA), Buenos Aires, \\ Argentina; \\ ${ }^{\dagger}$ deceased
}

\begin{abstract}
Two new species of Acanthobothrium Blanchard, 1848 were collected from rajiform batoids along the coast of Argentina. They are Acanthobothrium carolinae sp. n. from Bathyraja magellanica (Philippi) and Acanthobothrium domingae sp. n. from Dipturus brevicaudatus (Marini). Both belong to category 1 and 2 because their total length is lower than $15 \mathrm{~mm}$, they have fewer than 50 proglottids, fewer than 80 testes and a symmetric or asymmetric ovary. Acanthobothrium carolinae sp. n. differs from all congeners by the following combination of features: proglottid apolysis, hook morphology, microthrix pattern on the cephalic peduncle and distribution of the vitelline follicles. Acanthobothrium domingae sp. $\mathrm{n}$. is unique in the combination of proglottid apolysis, total length, number of proglottids, hook and septal morphology, microthrix pattern on the cephalic peduncle, number and distribution of testes, cirrus sac length, distribution of the vitelline follicles and genital pore position. The discovery of these species increases the number of species of Acanthobothrium parasitising rajiform batoids off Argentina from one to three. All three species have a unique pattern of distribution of the gladiate spinitriches along the length of the cephalic peduncle, i.e., gladiate spinitriches being interrupted in a medial line both dorsally and ventrally.
\end{abstract}

Keywords: Acanthobothrium carolinae sp. n., Acanthobothrium domingae sp. n., Bathyraja magellanica, Dipturus brevicaudatus.

Acanthobothrium Blanchard, 1848 includes 198 valid species, all of which are intestinal parasites of elasmobranchs (Caira et al. 2017, Franzese and Ivanov 2018, Maleki et al. 2018, 2019, Rodríguez-Ibarra et al. 2018, Zaragoza-Tapia et al. 2019). It shows the highest diversity within the order Onchoproteocephalidea (see Caira et al. 2017).

The genus has a wide geographical distribution and its species inhabit all oceans, except the Arctic and Antarctic Oceans. It also includes some freshwater species (Fyler 2009, 2011, Fyler and Caira 2010, Vardo-Zalik and Campbell 2011, Zschoche et al. 2011, Franzese and Ivanov 2018, Maleki et al. 2018, 2019, Zaragoza-Tapia et al. 2019).

The number of records of species of Acanthobothrium in different orders of batoids is usually proportional to the diversity of elasmobranchs within those orders (Franzese and Ivanov 2018). In this context, the number of hosts of Acanthobothrium spp. is expected to be similar in the Rajiformes and Myliobatiformes, as these orders are similarly diverse (Weigmann 2016). However, 24\% (50/210) of the species in the Myliobatiformes and 6\% (17/285) of the raji- forms have been reported as hosts of Acanthobothrium (see Caira et al. 2017, 2019). This difference might be due to the fact that less rajiforms have been examined for cestodes. From a total of 32 rajiform species from the Argentine shelf (Froese and Pauly 2019), only one has been reported as host for a species of Acanthobothrium (see Ivanov and Campbell 1998).

In a recent parasitological survey of parasites of batoids off Argentina, specimens of the rajiforms Bathyraja magellanica (Philippi) and Dipturus brevicaudatus (Marini) were examined, resulting in the discovery of two new species of Acanthobothrium. This is the first record of B. magellanica and D. brevicaudatus as hosts for Acanthobothrium. The new species are described herein.

\section{MATERIALS AND METHODS}

Cestodes were collected from the spiral intestines of four specimens of Bathyraja magellanica and four specimens of Dipturus brevicaudatus caught at different localities along the coast of Argentina. The specimens of B. magellanica were caught off 
Patagonian waters at $49^{\circ} 29^{\prime} \mathrm{S} ; 6^{\circ} 11^{\prime} \mathrm{W}$ off Puerto San Julián, Santa Cruz Province (host field numbers PD7-105, PD7-107) in March $2013,54^{\circ} 01^{\prime} \mathrm{S} ; 67^{\circ} 06^{\prime} \mathrm{W}$ off Río Grande, Tierra del Fuego Province (PD4-097) in April 2012, and 54 $32^{\prime} \mathrm{S}$; $60^{\circ} 01^{\prime} \mathrm{W}$ in Banco Burdwood (PD12-045) in March 2016. Three specimens of D. brevicaudatus were caught off coastal waters of Buenos Aires Province at $36^{\circ} 35^{\prime} \mathrm{S}$; 54 $54^{\circ} \mathrm{W}$ off Santa Teresita (PD5153, PD5-184) in August 2012 and 38 46'S; 57 $56^{\prime} \mathrm{W}$ off Puerto Quequén (AMPQ-251) in May 2010. An additional specimen of D. brevicaudatus was caught off Patagonian waters at $53^{\circ} 35^{\prime} \mathrm{S}$; 663'W off Río Grande (PD10-059) in April 2014. Hosts PD4, PD5, PD7, PD10 and PD12 were caught with bottom trawls on board of the Oceanographic Vessel Puerto Deseado (CONICET), and host AMPQ was caught by a commercial trawler. Five additional specimens of B. magellanica, caught off Tierra del Fuego Province (52 $31^{\circ} \mathrm{S}$; 66 $6^{\circ} 17^{\prime} \mathrm{W}$ in April 2012 and March 2014, and $55^{\circ} 03^{\prime} \mathrm{S} ; 66^{\circ} 07^{\prime} \mathrm{W}$ in March 2014) and Santa Cruz Province (51 $35^{\prime} \mathrm{S} ; 6^{\circ} 19^{\prime} \mathrm{W}$ in March 2013), were also examined but no onchoproteocephalideans were found. In addition, three uninfected specimens of $D$. brevicaudatus were caught off Buenos Aires Province (38 $\left.466^{\prime} \mathrm{S} ; 57^{\circ} 56^{\prime} \mathrm{W}\right)$ in July 2001 and July 2009, and two off Patagonian waters $\left(46^{\circ} 14^{\prime} \mathrm{S} ; 66^{\circ} 26^{\prime} \mathrm{W}\right.$ in April 2012 and 533' S; 66037'W in April 2014).

All tapeworms were removed from the spiral intestine of their respective host, fixed in 10\% formalin and transferred to $70 \%$ ethanol for storage. Specimens prepared for light microscopy were hydrated in a graded ethanol series, stained with Harris' haematoxylin, dehydrated in a graded ethanol series, cleared in methyl salicylate, and mounted in Canada balsam. Mature proglottids were removed and embedded in paraffin, and serially cross-sectioned at a thickness of $8 \mu \mathrm{m}$. Sections were stained with Harris' haematoxylin, counterstained with eosin, and mounted in Canada balsam. Eggs were obtained from gravid proglottids that were broken with needles, and prepared as temporary mounts using distilled water. Whole mounts, sections and temporary mounts were observed and measured using an Olympus BX51 compound microscope. Drawings were made with the aid of a drawing tube.

Measurements are expressed as a range, followed in parentheses by the mean, standard deviation, number of worms examined, and the total number of observations when more than one measurement per worm was taken. All measurements are in micrometres, unless otherwise stated. Hook measurements follow Ghoshroy and Caira (2001), modified by Campbell and Beveridge (2002). Worms prepared for scanning electron microscopy (SEM) were hydrated in a graded ethanol series, post-fixed in $1 \%$ osmium tetroxide overnight at room temperature, dehydrated in a graded ethanol series, and dried using hexamethyldisilazane. After dehydration, the specimens were mounted on stubs with carbon tape, coated with c. $40 \mathrm{~nm}$ of gold/palladium in a Thermo VG Scientific Polaron SC 7630 and examined in a Philips XL 30 scanning electron microscope

Terminology for microthrix shape and size follows Chervy (2009) and shape terminology for cirrus sac follows Clopton (2004). Valid host names follow Gabbanelli et al. (2018), Concha et al. (2019) and Froese and Pauly (2019). To facilitate comparisons between the new species of Acanthobothrium and those already described, the categorisation system of Ghoshroy and Caira (2001) was employed. Museum abbreviations used are as follows: IPCAS, Institute of Parasitology, Czech Academy of
Sciences, České Budějovice, Czech Republic; LRP, Lawrence R. Penner Parasitology Collection, Department of Ecology and Evolutionary Biology, University of Connecticut, Storrs, Connecticut, USA; MACN-Pa, Museo Argentino de Ciencias Naturales, Colección Parasitológica, Ciudad Autónoma de Buenos Aires, Argentina.

\section{RESULTS}

Acanthobothrium carolinae sp. n.

Figs. 1, 2

ZooBank number for species:

urn:lsid:zoobank.org:act: E3944371-4479-412F-AB8C-46330C1485A1

Description (based on 26 specimens as follows: whole mounts of 20 gravid worms, serial cross-sections of 1 worm and 5 worms examined with SEM). Worms 1.81$3.93 \mathrm{~mm}$ (2.52 $\pm 0.64 \mathrm{~mm}$; 12) long, 375-540 (454 \pm 55 ; 11) wide, maximum width at level of scolex; 8-17 (11 \pm 3 ; 17) proglottids, acraspedote, apolytic (Fig. 1A). Scolex 475-790 (614 \pm 104 ; 9) long, consisting of scolex proper with 4 bothridia and cephalic peduncle (Figs. 1A,C, 2A). Bothridia free posteriorly, vellum lacking, 350-450 (407 \pm 28 ; 17) long, 173-275 (218 \pm 31 ; 15) wide, each with 3 loculi and specialised anterior region in form of muscular pad (Figs. 1C, 2A); muscular pad falciform with extended posterolateral margins (Fig. 2B), 48-88 (65 \pm 12 ; 14) long, 70-103 (84 $\pm 11 ; 14)$ wide, bearing accessory sucker and one pair of hooks; accessory sucker $23-45$ (34 \pm 7 ; 12) long, 30-60 (43 $\pm 8 ; 12)$ wide. Bothridial anterior loculus 180-275 (232 $\pm 26 ; 14)$ long, middle loculus 60-100 (77 \pm 11 ; 14) long, posterior loculus 43-63 (53 \pm 6 ; 14) long; loculus length ratio (anterior: middle: posterior) 1: 0.3-0.6 $(0.3 \pm 0.08 ; 14): 0.2-0.3(0.2 \pm 0.03 ; 14)$ (Fig. 1C).

Hooks bipronged, hollow, with tubercle on proximal surface of axial prong; internal channels of axial and abaxial prongs continuous; axial prongs longer than abaxial prongs; lateral and medial hooks equal in size (Fig. 1B). Lateral hook measurements $(\mathrm{n}=12)$ : A 28-35 $(31 \pm 2)$, B 40-53 (46 \pm 4$),$ C 23-35 (30 \pm 4$),$ D 65-80 (73 \pm 4$),$ E 53-68 (60 \pm 5$)$, W 20-33 (27 \pm 4$)$. Medial hook measurements $(\mathrm{n}=12)$ : A' 28-33 (30 \pm 2$), \mathrm{B}^{\prime} 43-53(48 \pm 3), \mathrm{C}^{\prime}$ 18-35 (29 \pm 6$)$, D’ 68-80 (74 \pm 5$)$, E’ 48-68 (59 \pm 7$)$, W' 15-33 (24 \pm 4$)$. Base of medial hook overlaps base of lat-

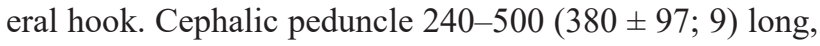
$103-158(140 \pm 16 ; 11)$ wide at posterior end.

Apex of scolex, distal and proximal surface of muscular pads, accessory suckers and distal bothridial surfaces covered with papilliform filitriches (Fig. 2B,C). Proximal surface of bothridia covered with papilliform filitriches, interspersed with gladiate spinitriches at level of anterior loculus close to scolex proper (Fig. 2D). Scolex proper with gladiate spinitriches and papilliform filitriches. Cephalic peduncle covered with gladiate spinitriches and papilliform filitriches (Fig. 2F), except on most anterior region, and a well-defined longitudinal band on mid-dorsal and mid-ventral surfaces, covered only by papilliform filitriches (Fig. 2E-F). 
A

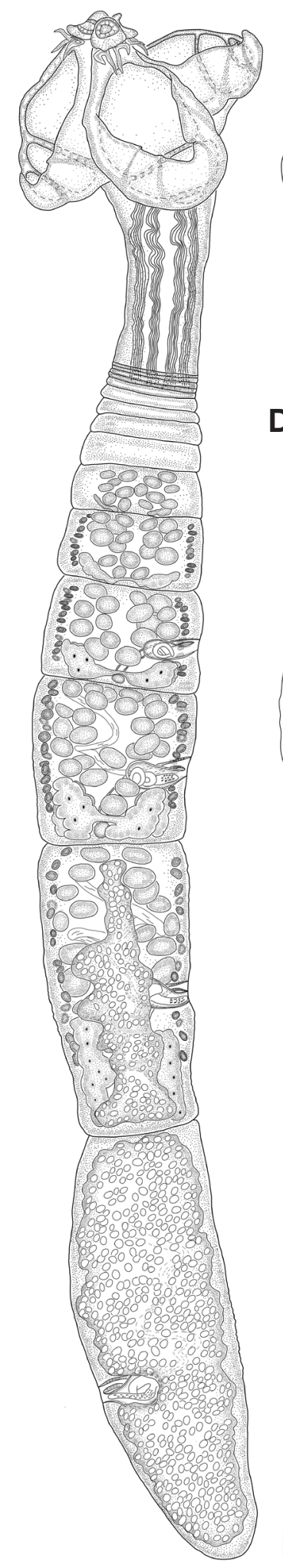

B

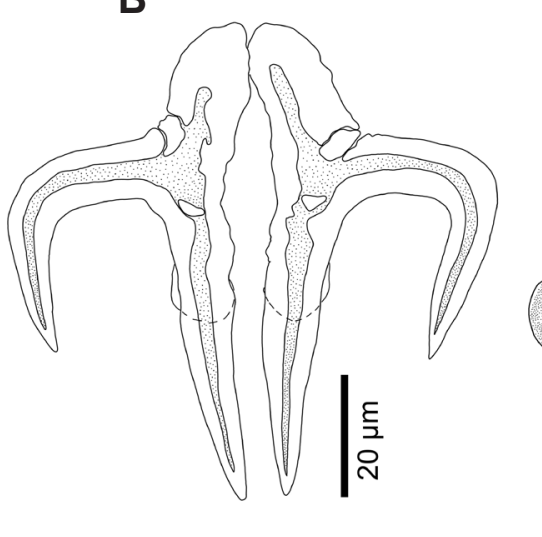

D

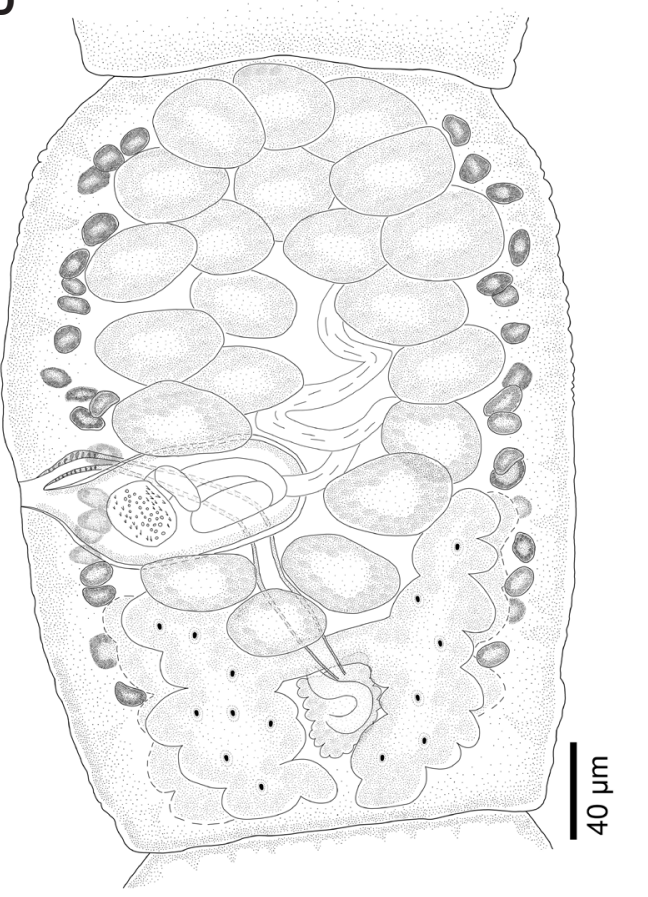

C
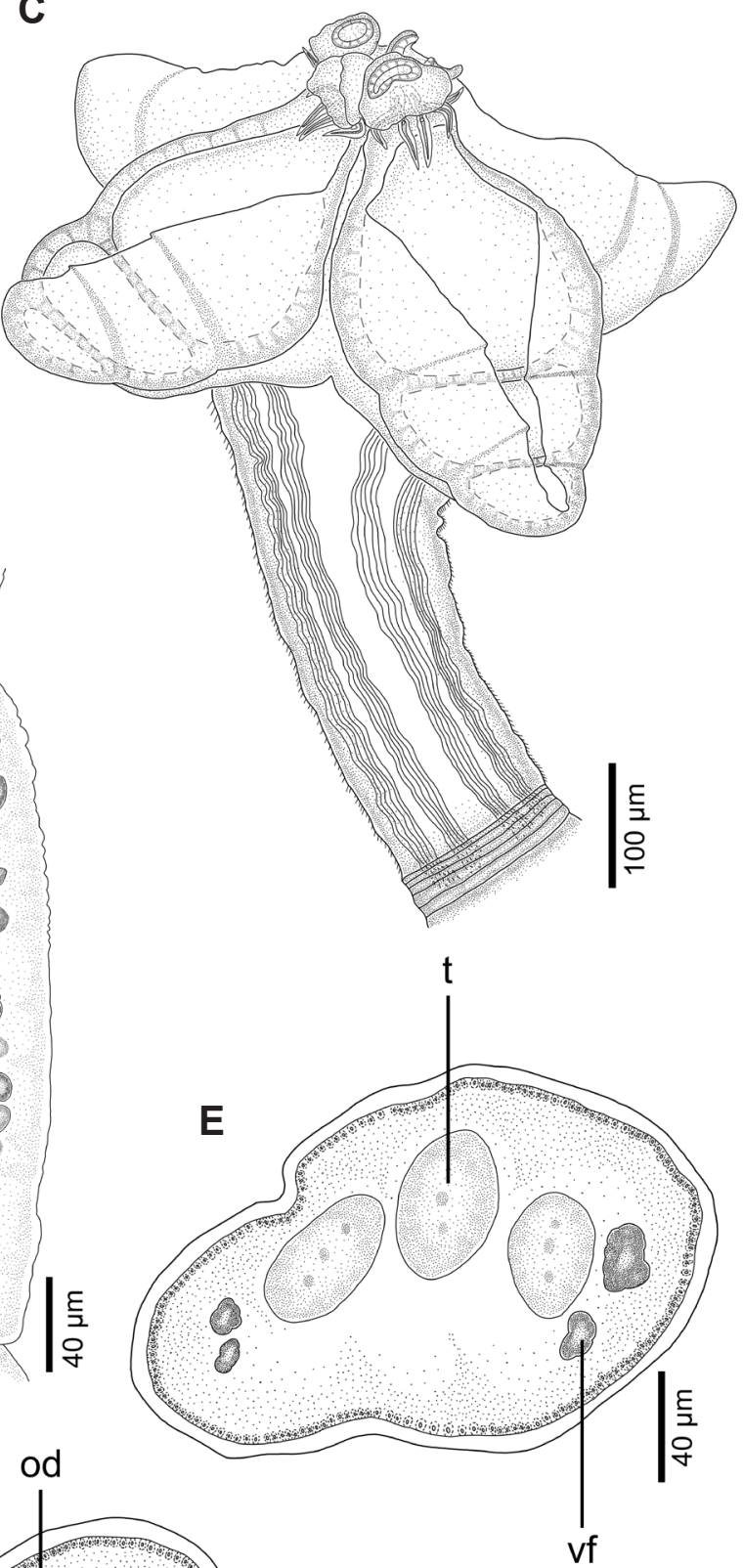

$\frac{\xi}{2}$

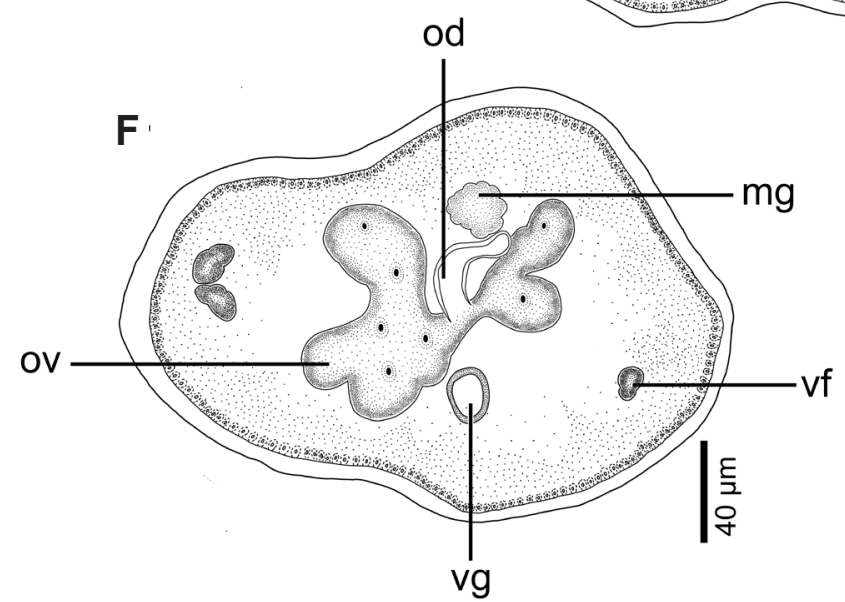

Fig. 1. Acanthobothrium carolinae sp. n. from Bathyraja magellanica (Philippi). A - entire gravid worm (holotype MACN-Pa No. 716); B - detail of hooks (paratype IPCAS No. C-838); C - scolex (paratype MACN-Pa No. 717/1); D - mature proglottid (paratype MACN-Pa No. 718/2); E - cross section at the level of testes anterior to the cirrus sac (paratype MACN-Pa No. 717/3); F - cross section at level of ovarian isthmus (paratype MACN-Pa No. 717/4). Abbreviations: mg - Mehlis' gland; od - oviduct; ov - ovary; $\mathrm{t}-$ testes; vf - vitelline follicle; vg - vagina. 

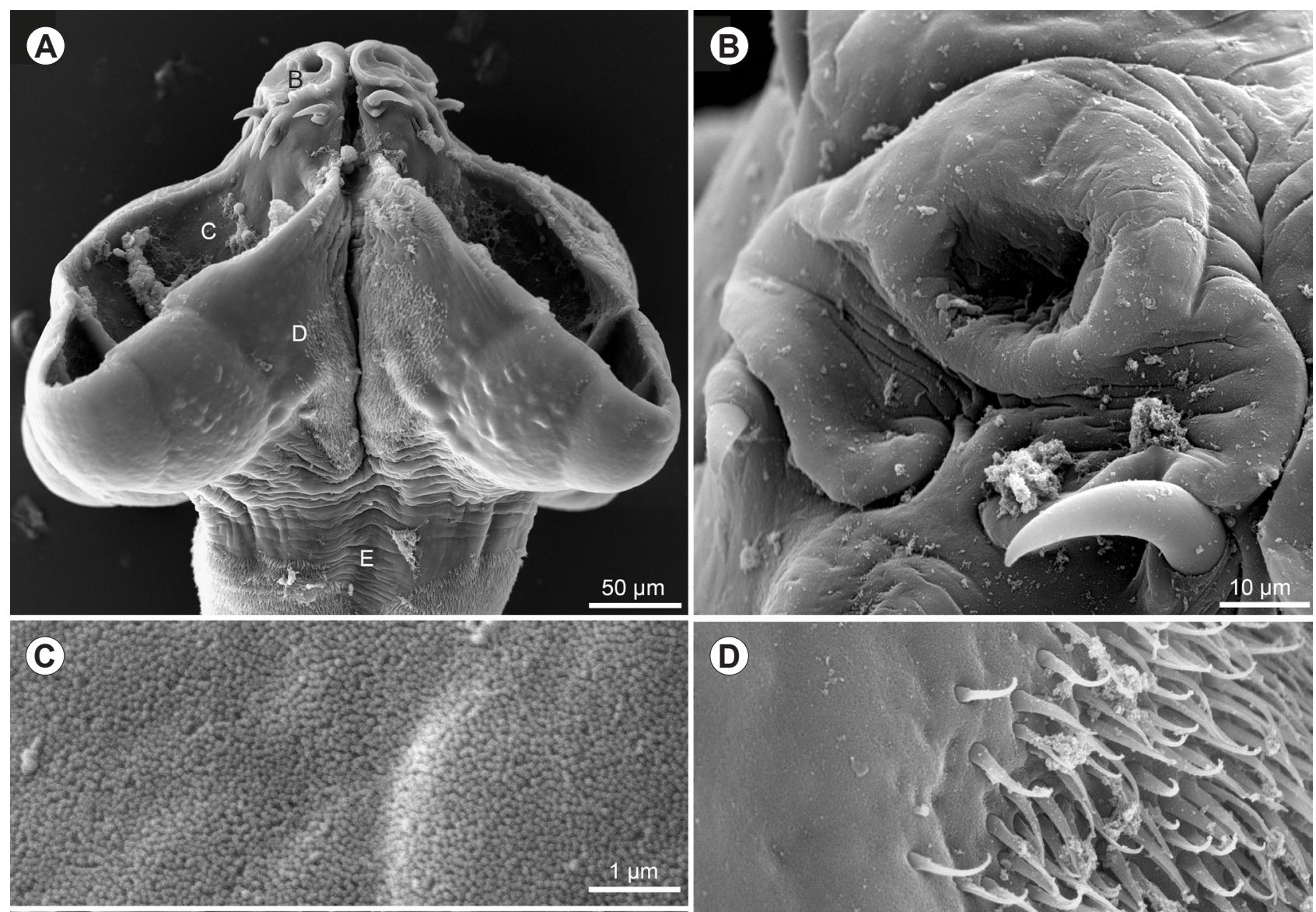

(D)
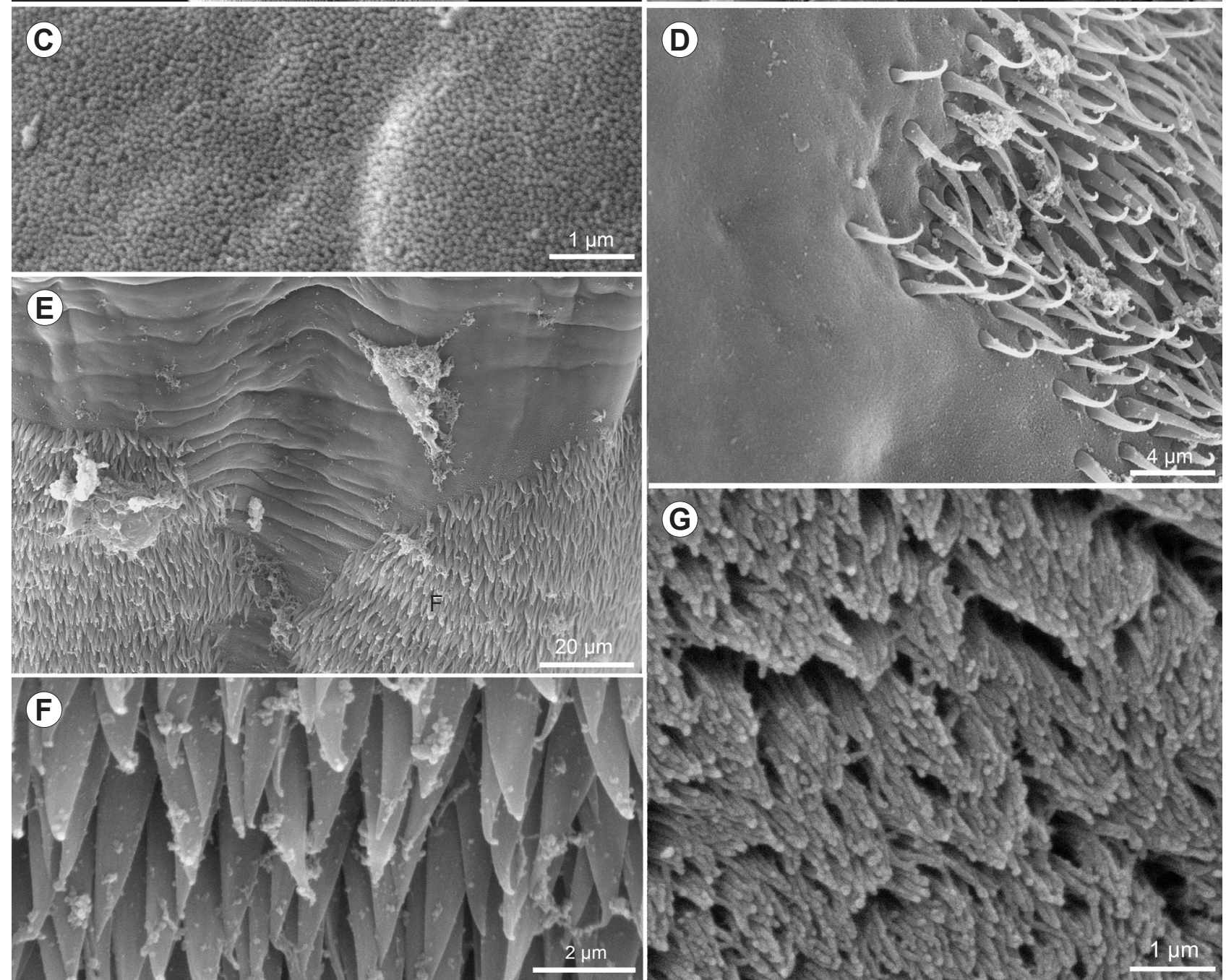

Fig. 2. Acanthobothrium carolinae sp. n. from Bathyraja magellanica (Philippi), scanning electron micrographs. A - scolex, small letters indicate the locations of details shown in Fig. 2B-E; B - bothridial muscular pad; C - distal bothridial surface; D - proximal bothridial surface; $\mathbf{E}$ - cephalic peduncle, small letter indicates the location of detail shown in Fig. 2F; $\mathbf{F}-$ surface of the cephalic peduncle; $\mathbf{G}$ - surface of mature proglottid. 
Immature proglottids initially wider than long, becoming longer than wide with maturity. Mature proglottids 275-630 (378 $\pm 109 ; 16)$ long, 198-380 (291 $\pm 51 ; 16)$ wide, $0-3(1 \pm 1 ; 18)$ per strobila, covered with capilliform filitriches (Fig. 2G). Testes oval, 20-45 (32 $\pm 6 ; 8 ; 40)$ long, 35-65 (48 $\pm 8 ; 8 ; 40)$ wide, arranged in 3-4 irregular columns, extending from anterior margin of proglottid to ovarian isthmus (Fig. 1D), 1 layer deep (Fig. 1E), 20-29 $(24 \pm 3 ; 10)$ in total number, $1-4(2 \pm 1 ; 10)$ postvaginal testes (Fig. 1D). Cirrus sac oval, 68-175 (115 $\pm 30 ; 10)$ long, $43-78(56 \pm 10 ; 10)$ wide, containing coiled cirrus covered with spinitriches; vas deferens bulk occupying midline of proglottids, running from proximal margin of cirrus sac to first third of proglottid length, entering cirrus sac at medial margin (Fig. 1D). Genital pores marginal, 30-46\% (39 \pm 5 ; 14) of proglottid length from posterior end.

Vagina thick-walled, surrounded by darkly stained cells distally, crossing cirrus sac dorsally, extending posteriorly along midline of proglottid, reaching ootype (Fig. 1D); vaginal sphincter absent. Ovary near posterior end of proglottid, tetralobed in cross-section (Fig. 1F), H-shaped in dorsoventral view (Fig. 1D), symmetrical (36\% of specimens) or asymmetrical (64\% of specimens). Poral lobe 110-220 (148 $\pm 37 ; 9)$ long, aporal lobe 123-250 (172 \pm 47; 9) long; width at ovarian isthmus 140-225 (180 \pm 31 ; 7). Mehlis' gland posterior to ovarian isthmus, 31-62 (45 $\pm 13 ; 4)$ in diameter (Fig. 1D). Vitelline follicles 8-21 (12 \pm 3 ; 5; 25) long, 15-28 (22 \pm 3 ; 5; 25) wide, in 1 dorsal and 1 ventral column on each lateral margin of proglottid, extending from near anterior margin of proglottid to level of ovarian isthmus, interrupted by vagina and cirrus sac ventrally (Fig. 1D). Uterus not observed in mature proglottids. Terminal gravid proglottid 535-1,110 (797 \pm 164; 18) long, 210-380 (293 \pm 49 ; 18) wide; $1-2$ ( $1 \pm 0.5$; 18) gravid proglottids per strobila (Fig. 1A). Intrauterine unembryonated eggs subspherical, 17-21 (19 $\pm 1 ; 2 ; 20)$ long, 14-20 (17 $\pm 2 ; 2 ; 20)$ wide.

Type host: Bathyraja magellanica (Philippi), Magellan skate (Rajiformes: Arhynchobatidae).

Type 1ocality: Coastal waters off Puerto San Julián, Santa Cruz Province ( $\left.49^{\circ} 29^{\prime} \mathrm{S} ; 66^{\circ} 11^{\prime} \mathrm{W}\right)$ (host PD7-105).

Additional 1 ocalities: Coastal waters off Río Grande, Tierra del Fuego Province $\left(54^{\circ} 01^{\prime} \mathrm{S} ; 6^{\circ} 06^{\prime} \mathrm{W}\right)$ (host PD4097), off Banco Burdwood (5432'S; 6001'W) (host PD12045).

Site of infection: Spiral intestine.

Specimens deposited: Holotype MACN-Pa No. 716 (1 gravid worm), 8 paratypes MACN-PaNos. 717/1-4,718/1-3, 719/1-2 (7 gravid worms and histological sections of 1 mature proglottid); 6 paratypes IPCAS No. C-838 (6 gravid worms); 6 paratypes LRP Nos. 10179-10184 (6 gravid worms).

Prevalence of infection: $44 \%$ (4 hosts infected out of 9 examined).

Etymology: This species is named after Carolina Tropea, first author's fiancé

Remarks. Acanthobothrium carolinae sp. n. is compared to species in category 1 and 2 by being less than $15 \mathrm{~mm}$ in total length and having fewer than 50 proglottids, fewer than 80 testes and a symmetric or asymmetric ovary (Ghoshroy and Caira 2001). The new species can be distinguished from the 78 euapolytic and four hyperapolytic species belonging to category 1 and 2 (Ghoshroy and Caira 2001, Fyler and Caira 2006, Franzese and Ivanov 2018, Maleki et al. 2018, 2019, Zaragoza-Tapia et al. 2019 and citations therein) by the type of apolysis.

Among the species of Acanthobothrium in category 1 and 2 that are apolytic or have a doubtful apolysis (Franzese and Ivanov 2018, Maleki et al. 2019), A. carolinae sp. n. can be distinguished as follows:

In $A$. carolinae the abaxial prong is conspicuously shorter and strongly curved than the axial prong, while in Acanthobothrium annapinkiensis Carvajal et Goldstein, 1971, A. batailloni Euzet, 1955, A brachyacanthum Riser, 1955, A. coquimbensis Carvajal et Jeges, 1980 and A. dujardini van Beneden, 1850, the axial and abaxial prongs are almost of equal size.

Whereas in $A$. carolinae the vitelline follicles extend posteriorly from the anterior margin of the proglottid to the ovarian isthmus, they reach the posterior margin of the ovary in Acanthobothrium edwardsi Williams, 1969, A. jalalii Maleki, Malek et Palm, 2013, A. lilium Baer et Euzet, 1962, A. nanogravidum Zschoche, Caira et Fyler, 2011, A. quadripartitum Williams, 1968 and A. tasajerasi Brooks, 1977.

Finally, a longitudinal band lacking spinitriches on mid-dorsal and mid-ventral surfaces of the cephalic peduncle in A. carolinae distinguishes this new species from Acanthobothrium halehae Maleki, Malek et Palm, 2019 and A. makranense Maleki, Malek et Palm, 2019.

Acanthobothrium domingae sp. n.

Figs. 3-5

ZooBank number for species:

urn:Isid:zoobank.org:act: DEF84059-387A-4CE8-827E-0300A1842FA7

Description (based on 40 specimens prepared as follows: whole mounts of 28 mature and 9 gravid worms, serial cross-sections of 1 worm and 2 specimens examined with SEM). Gravid worms 3.5-5.4 mm (4.2 $\pm 0.6 \mathrm{~mm}$; 9) long, 355-585 (459 \pm 69 ; 14) wide, maximum width at level of scolex; 14-18 (16 $\pm 1 ; 8)$ proglottids, acraspedote, apolytic (Fig. 3A). Scolex 575-1,530 (922 $\pm 233 ; 26)$ long, consisting of scolex proper with 4 bothridia and cephalic peduncle (Figs. 3A,C, 4A). Bothridia joined by velum at level of middle loculus (Figs. 3C, 4A), 475-700 (567 \pm 56 ; 25) long, 183-325 (255 $\pm 40 ; 24)$ wide, each with 3 loculi and specialised anterior region in form of muscular pad (Figs. 3C, 4A); muscular pad falciform with irregular scalloped edges in extended posterolateral margins (Fig. 4B), 60-113 (87 \pm 17 ; 19) long, 135-210 (171 $\pm 24 ; 23)$ wide, bearing accessory sucker and one pair of hooks. Accessory sucker 30-50 (40 \pm 6 ; 17) long, 55-103 (79 \pm 13 ; 17) wide. Bothridial anterior loculus 220-445 (356 \pm 51 ; 23) long, middle loculus 53-100 (78 $\pm 11 ; 23)$ long, posterior loculus 53-120 (92 $\pm 18 ; 22)$ long; loculus length ratio (anterior: middle: posterior) 1: $0.2-0.3(0.2 \pm 0.03 ; 23)$ : 
A

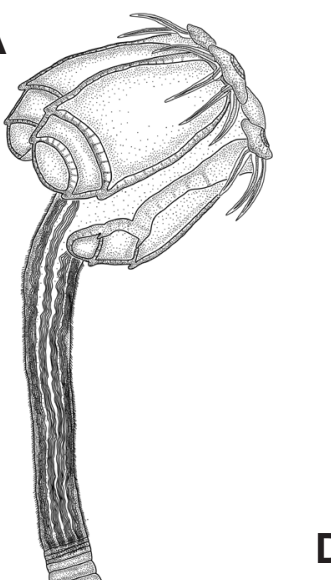

D
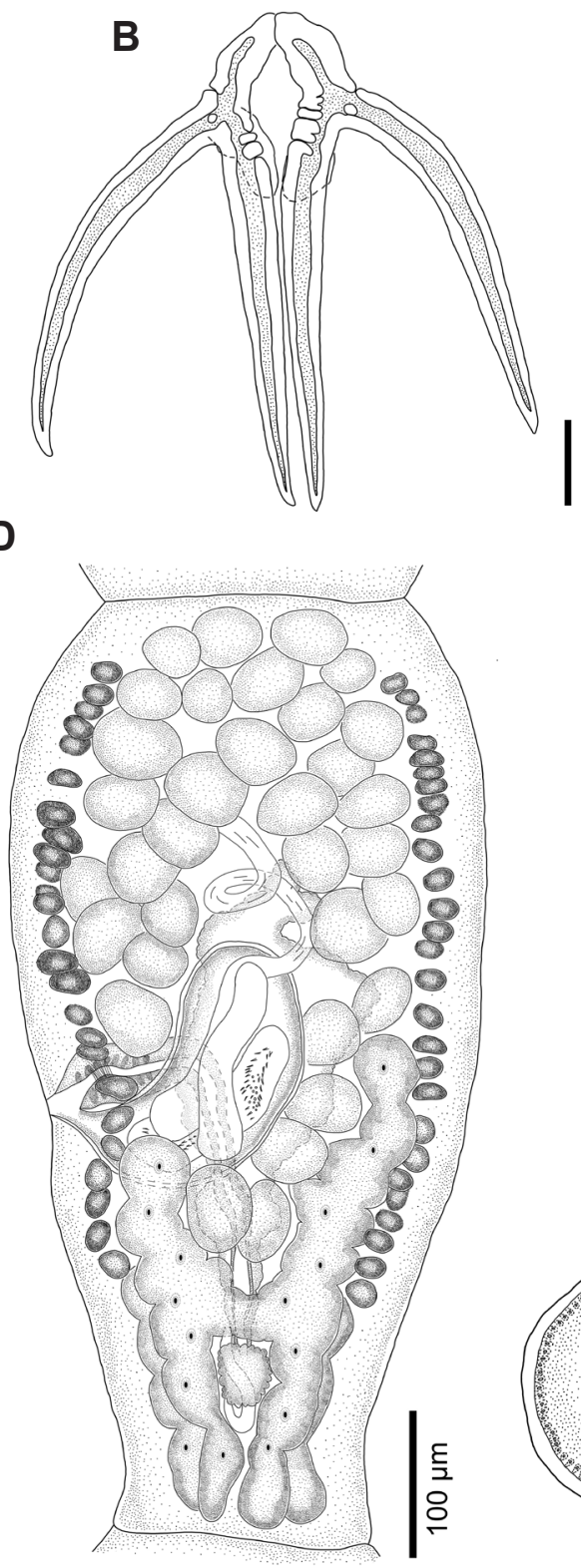

C
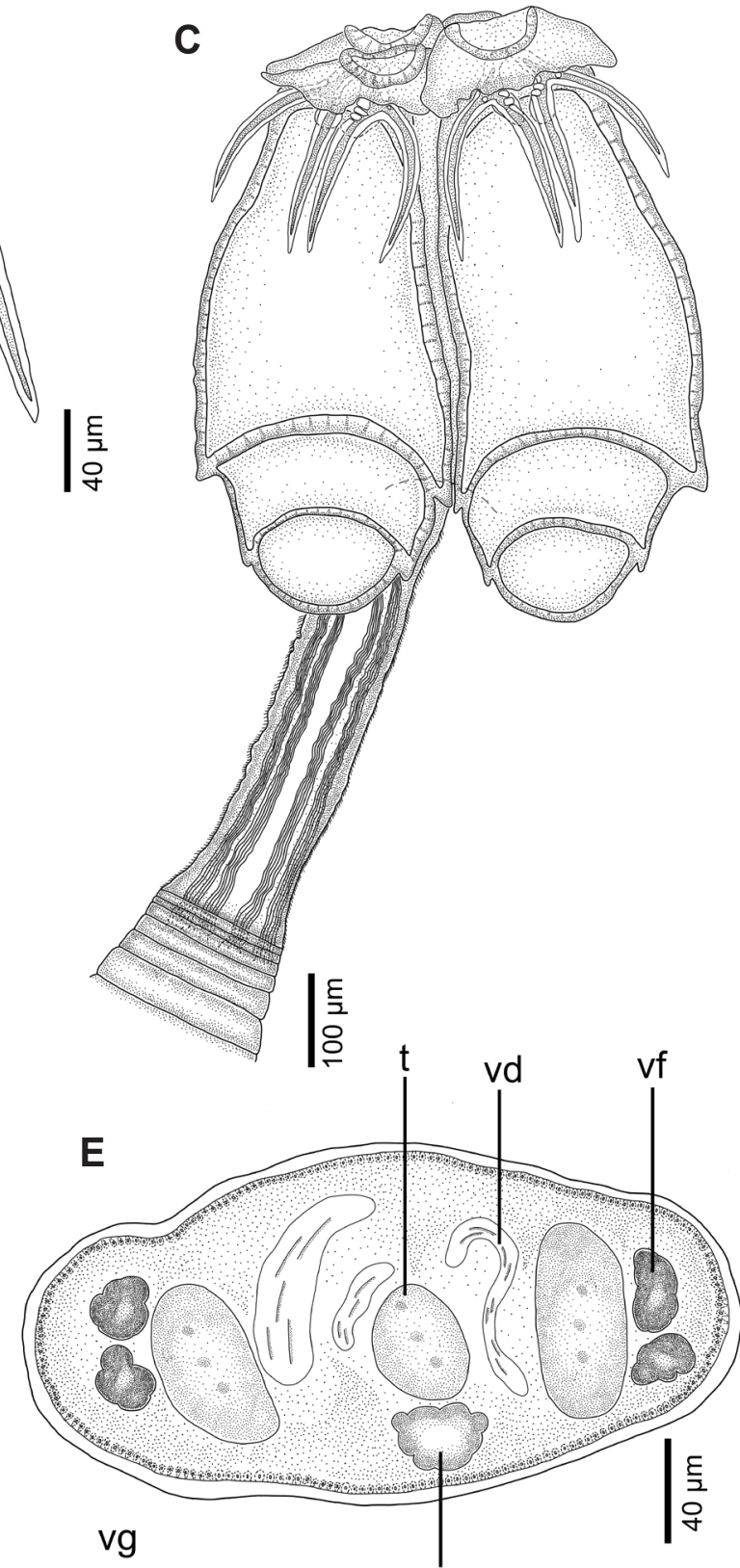

ut

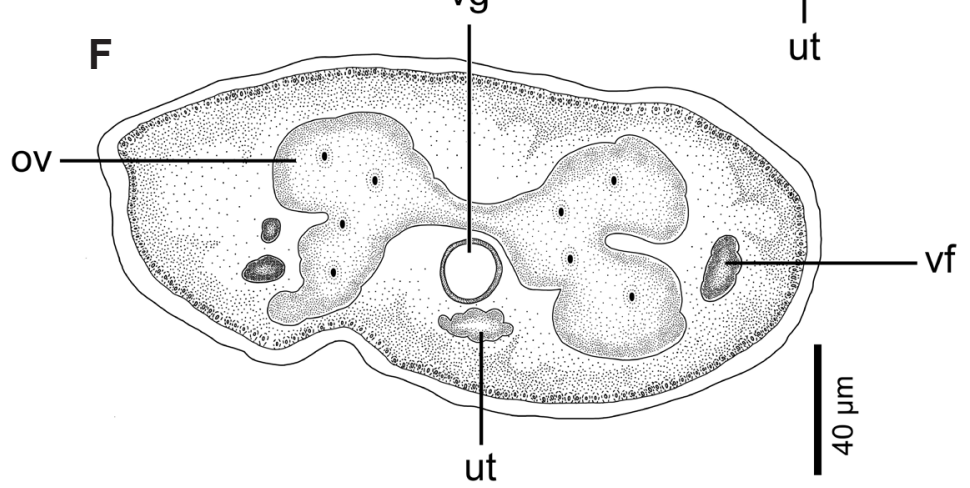

Fig. 3. Acanthobothrium domingae sp. n. from Dipturus brevicaudatus (Marini). A - entire gravid worm (holotype MACN-Pa No. 720); B - detail of hooks (paratype MACN-Pa No. 722/6); C - scolex (paratype MACN-Pa No. 722/3); D - mature proglottid (holotype MACN-Pa No. 720); $\mathbf{E}$ - cross section at level of testes anterior to the cirrus sac (paratype MACN-Pa No. 722/8); $\mathbf{F}$ - cross section at level of ovarian isthmus (paratype MACN-Pa No. 722/9). Abbreviations: ov - ovary; $t$ - testes; ut - uterus; vd - vas deferens; vf vitelline follicle; vg - vagina. 

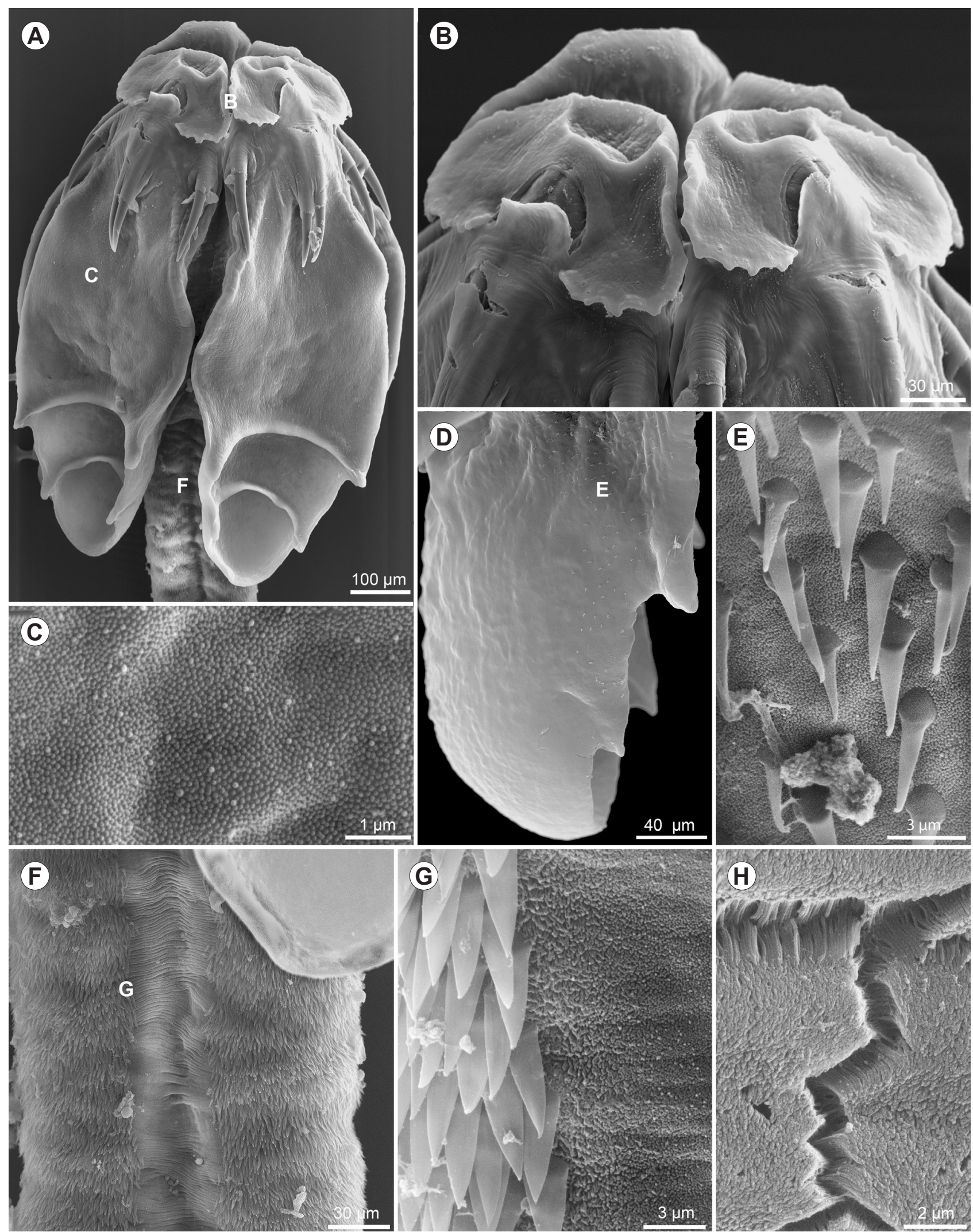

Fig. 4. Acanthobothrium domingae sp. n. from Dipturus brevicaudatus (Marini), scanning electron micrographs. A - scolex, small letters indicate the locations of details shown in Fig. 4B-C, F; B - bothridial muscular pad; C - distal bothridial surface; D - proximal bothridial surface, small letter indicates the location of detail shown in Fig. 4E; $\mathbf{E}$ - detail of proximal bothridial surface; $\mathbf{F}$ - cephalic peduncle, small letter indicates the location of detail shown in Fig. 4G; $\mathbf{G}$ - surface of cephalic peduncle; $\mathbf{H}$ - surface of mature proglottid. 
$0.2-0.3(0.3 \pm 0.05 ; 22)$ (Figs. 3C, 4A). Septa extending beyond lateral margins of bothridia (Figs. 3C, 4A,D).

Hooks bipronged, hollow, with tubercle on proximal surface of axial prong; internal channels of axial and abaxial prongs continuous; axial prongs as long as abaxial prongs; lateral and medial hooks equal in size (Fig. 3B). Lateral hook measurements $(n=25)$ : A 45-68 $(59 \pm 6)$, B 128-180 (159 \pm 12$), C$ 125-170 (151 \pm 12$),$ D 168-238 $(209 \pm 16)$, E $170-235(209 \pm 15), W 68-125(96 \pm 15)$. Medial hook measurements $(n=26)$ : A' 43-68 $(58 \pm 6)$, B'

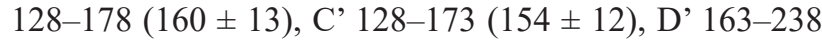

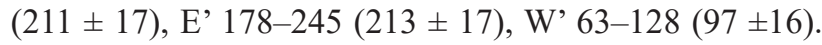
Bases of lateral and medial hooks slightly overlap interchangeably. Cephalic peduncle 205-1,110 (545 $\pm 242 ; 24)$ long, $75-155(113 \pm 22 ; 19)$ wide at posterior end.

Distal and proximal surface of muscular pads, accessory suckers and distal bothridial surfaces covered with papilliform filitriches (Fig. 4B,C). Most of proximal surface of bothridia covered with papilliform filitriches, interspersed with gladiate spinitriches close to bothridial rim at level of anterior and middle loculi (Fig. 4D,E). Scolex proper and velum covered with papilliform filitriches. Cephalic peduncle covered with gladiate spinitriches and acicular filitriches except for well-defined band on mid-dorsal and mid-ventral surfaces that are covered only by acicular filitriches (Fig. 4F,G).

Immature proglottids initially wider than long, becoming longer than wide with maturity. Mature proglottids 385-1,435 (902 \pm 273 ; 32) long, 183-415 (262 $\pm 60 ; 32)$ wide, $1-2(2 \pm 1 ; 8)$ per strobila, covered with capilliform filitriches (Fig. 4H). Testes oval, 25-48 (33 $\pm 5 ; 13 ; 65)$ long, 35-68 $(49 \pm 6 ; 13 ; 65)$ wide, arranged in 3-5 irregular columns (Fig. 3D), 1 layer deep (Fig. 3E), 26-36 (30 $\pm 3 ; 18)$ in total number, $1-4(2 \pm 1 ; 18)$ in postporal field (Fig. 3D). Cirrus sac strongly curved anteriorly, 163-260 (204 $\pm 24 ; 16)$ long, 85-163 (127 $\pm 22 ; 16)$ wide, containing coiled cirrus covered with spinitriches; vas deferens bulk occupying midline of proglottid from middle of cirrus sac to anterior third of proglottid length, entering cirrus sac on its anterior margin (Fig. 3D). Genital pores marginal, at $35-55 \%(50 \pm 5 ; 23)$ of proglottid length from posterior end.

Vagina thick-walled, surrounded by darkly stained cells distally, crossing cirrus sac ventrally, extending posteriorly along midline of proglottid, reaching ootype (Fig. 3D); vaginal sphincter present (Fig. 3D). Ovary at posterior end of proglottid, H-shaped in dorsoventral view (Fig. 3D), tetralobed in cross-section (Fig. 3F), symmetrical $(50 \%$ of specimens) or asymmetrical (50\% of specimens); poral lobe 120-490 (334 $\pm 106 ; 18)$ long; aporal lobe 178-595 (361 $\pm 108 ; 18)$ long, width at ovarian isthmus 73-208 $(111 \pm 33 ; 14)$. Mehlis' gland posterior to ovarian isthmus, $23-50(35 \pm 10 ; 5)$ in diameter (Fig. 3D). Vitelline follicles 10-40 (20 \pm 7 ; 10; 50) long, 10-35 (23 $\pm 6 ; 10 ; 50)$ wide, in 1 dorsal and 1 ventral column on each lateral margin of proglottid, extending from near anterior margin of proglottid to level of ovarian isthmus, interrupted by vagina and cirrus sac ventrally (Fig. 3D). Uterus sacciform, occupying midline of proglottid, extending from ootype to anterior third of proglottid length (Fig. 3D). Terminal gravid proglottid 960-1,650 (1,235 \pm 225 ; 8) long, 270-480 (354 \pm $69 ; 8)$ wide, $1-2(2 \pm 1 ; 8)$ per strobila (Fig. 3A). Intrauterine unembryonated eggs subspherical, 18-21 (19 $\pm 1 ; 2$; 20) long, 15-20 (17 $\pm 1 ; 2$; 20) wide (Fig. 5).

Type host: Dipturus brevicaudatus (Marini), short tail yellownose skate (Rajiformes: Rajidae).

Type locality: Coastal waters off Santa Teresita, Buenos

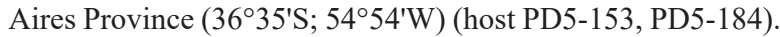

Additi on a 11 o c a lity: Coastal waters off Río Grande, Tier-

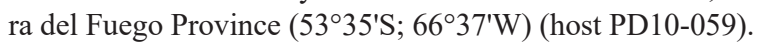

Site of infection: Spiral intestine.

Specimens deposited: Holotype MACN-Pa No. 720 (gravid worm), 12 paratypes MACN-Pa Nos. 721/1-3, 722/19, 723, (8 mature worms, 3 gravid worms and histological sections of 1 mature proglottid); 13 paratypes IPCAS No. C-839 (11 mature worms, 2 gravid worms); 12 paratypes LRP Nos. 10185-10195 (9 mature worms, 3 gravid worms).

Prevalence of infection: $44 \%$ (4 hosts infected out of 9 examined).

Etymology: This species is named in memory of Dominga De Vita, first author's grandmother.

Remarks. Acanthobothrium domingae sp. n. is a category 1 and 2 species (i.e., it is less than $15 \mathrm{~mm}$ in total length, has fewer than 50 proglottids, fewer than 80 testes and a symmetric or asymmetric ovary) (Ghoshroy and Caira 2001). The new species can easily be differentiated from the four hyperapolytic species belonging to category 1 and 2 (Franzese and Ivanov 2018) by the type of apolysis, and from the remaining species of both categories as follows:

The laterally extending bothridial septa and the longitudinal bands lacking spinitriches on mid-dorsal and mid-ventral surfaces of the cephalic peduncle differentiate A. domingae sp. n. from: Acanthobothrium asnihae Fyler et Caira, 2006; A. asrinae Maleki, Malek et Palm, 2015; A. bobconniorum Fyler et Caira, 2010; A. chabahariense Maleki, Malek et Rastgoo, 2018; A. dasi Ghoshroy et Caira, 2001; A. dollyae Caira et Burge, 2001; A. foulki Reyda et Caira, 2006; A. fylerae Maleki, Malek et Palm, 2015; A. gnomus Reyda et Caira, 2006; A. jalalii; A. janineae Maleki, Malek et Palm, 2015; A. jeanneae Fyler et Caira, 2010; A. larsoni Reyda et Caira, 2006; A. lepidum Reyda et Caira, 2006; A. marymichaelorum Twohig, Caira et Fyler, 2008; A. masnihae Fyler et Caira, 2006; A. nanogravidum; A. oceanharvestae Fyler, Caira et Jensen, 2009; A. peruviense Reyda, 2008; A. popi Fyler, Caira et Jensen, 2009; A. rajivi Ghoshroy et Caira, 2001; A. romanowi Fyler, Caira et Jensen, 2009; A. royi Caira et Burge, 2001; A. saliki Fyler et Caira, 2006; A tetabuanense Reyda et Caira, 2006; A. zainali Fyler et Caira, 2006, and A. zimmeri Fyler, Caira et Jensen, 2009.

Acanthobothrium domingae sp. $\mathrm{n}$. is longer than A. atahualpai Marques, Brooks et Barriga, 1997 and A. brevissime Linton, 1908 (3.5-5.4 mm vs. $2.1 \mathrm{~mm}$ and $1.4 \mathrm{~mm}$, respectively) and has a greater number of proglottids than A. dujardini (14-18 vs. 8-12, respectively).

Also, the new species has hooks with axial and abaxial prongs longer than A. brachyacanthum; A. bullardi Gho- 


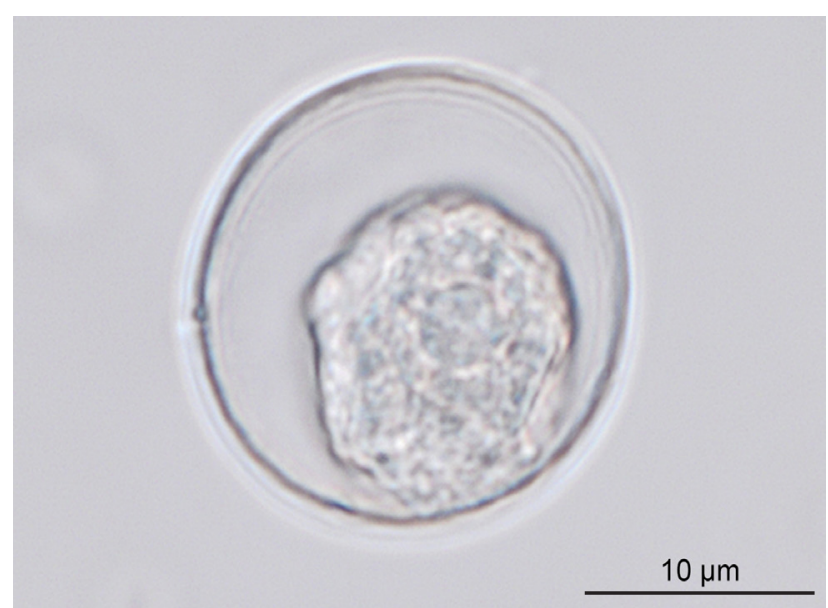

Fig. 5. Acanthobothrium domingae sp. n. from Dipturus brevicaudatus (Marini), temporary mount of eggs.

shroy et Caira, 2001; A. campbelli Marques, Brooks et Monks, 1995; A. carolinae sp. n., A. chisholmae Campbell et Beveridge, 2002; A. cimari Marques, Brooks et Monks, 1995; A. costarricense Marques, Brooks et Monks, 1995; A. edwardsi; A. fogeli Goldstein, 1964; A. gloveri Campbell et Beveridge, 2002; A. halehae; A. himanturi Brooks, 1977; A. kurdistanense Maleki, Malek et Palm, 2019; A. lasti Campbell et Beveridge, 2002; A. laurenbrownae Campbell et Beveridge, 2002; A. lentiginosum Vardo-Zalik et Campbell, 2011; A. makranense; A. marplatensis Ivanov et Campbell, 1998; A. minus Tazerouti, Kechemir-Issad et Euzet, 2009; A. minusculus Marques, Brooks et Barriga, 1997; A. monksi Marques, Brooks et Barriga, 1997; A. mooreae Campbell et Beveridge, 2002; A. ocallaghani Campbell et Beveridge, 2002; A. odonoghuei Campbell et Beveridge, 2002; A. olseni Dailey et Mudry, 1968; A. omanense Maleki, Malek, et Palm, 2019; A. persicum Maleki, Malek et Palm, 2019; A. puntarenasense Marques, Brooks et Monks, 1995; A. quadripartitum; A. rohdei Campbell et Beveridge, 2002; A. soniae Zaragoza-Tapia, Pulido-Flores, Violante-González et Monks, 2019; A. southwelli Subhapradha, 1955; A. sphaera Maleki, Malek et Palm, 2013; A. stevensi Campbell et Beveridge, 2002; A. thomasae Campbell et Beveridge, 2002; A. tripartitum Williams, 1969; A. ulmeri Vardo-Zalik et Campbell, 2011; A. unilateralis Alexander, 1953; A. urotrygoni Brooks et Mayes, 1980; A. vargasi Marques, Brooks et Monks, 1995; A. westi Vardo-Zalik et Campbell, 2011 and $A$. woodsholei Baer, 1948 (within a range of 125-180 in A. domingae sp. n. vs. 33-120 in these other species). Whereas in A. domingae sp. n. the axial and abaxial prongs are almost of the same size, in A. clarkeae Campbell et Beveridge, 2002 and A. paulum Linton, 1890 the axial prong is conspicuously longer than the abaxial prong.

Acanthobothrium domingae differs from A. annapinkiensis by having shorter mature proglottids (385-1,435 vs. 1,600), shorter gravid proglottids (960-1,650 vs. 2,200) and shorter bothridia (475-700 vs. 740-900).

A. domingae sp. n. differs from A. brayi Campbell et Beveridge, 2002; A. schalli Vardo-Zalik et Campbell, 2011 and $A$. walkeri Campbell et Beveridge, 2002 by having a longer cirrus sac (163-260 vs. 141-152, 70-120 and 90-115, respectively). Also, A. annapinkiensis; A. bartonae Campbell et Beveridge, 2002; A. batailloni; A. coquimbensis; A. guanghaiense Yang, Sun, Zhi, Iwaki, Reyda et Yang, 2016; A. hypermekkolpos Fyler et Caira, 2010; A. jamesi Maleki, Malek et Palm, 2015; A. lilium; A. lineatum Campbell, 1969; A. martini Campbell et Beveridge, 2002; A. mathiasi Euzet, 1959; A. nicoyaense Brooks et McCorquodale, 1995; A. semnovesiculum Verma, 1928; A. tasajerasi and A. urolophi Schmidt, 1973 differ from $A$. domingae by having vitelline follicles reaching the posterior end of the ovary, whereas the vitelline follicles extend posteriorly to the ovarian isthmus in the new species.

\section{DISCUSSION}

The present study increases the number of known species of Acanthobothrium parasitising rajiform batoids off Argentina from one to three. Most of this genus species in rajiforms around the world (20/24), including Acanthobothrium domingae sp. n., were found in batoids of the family Rajidae (Caira et al. 2017). This proportion is consistent with the relationship between reports of Acanthobothrium spp. and elasmobranch's diversity (Franzese and Ivanov 2018), Rajidae being the most diverse family of rajiforms, with 164 species (Weigmann 2016). The majority of these species of Acanthobothrium occurs in the North Atlantic Ocean (Goldstein 1964, Fyler and Caira 2006, Tazerouti et al. 2009, Vardo-Zalik and Campbell 2011), where the diversity of rajids is greatest (Weigmann 2016). The remaining species parasitising rajiforms, including Acanthobothrium carolinae sp. n., were found in batoids belonging to the family Arhynchobatidae (see Caira et al. 2017), which represents the second most diverse family of rajiforms, with 100 species (Weigmann 2016).

The presence of only four Acanthobothrium species in batoids belonging to that family is surprising considering its great diversity. All four species occur in waters of the Atlantic and Pacific Oceans in South America. Two of them occur particularly in the Argentine Sea (Carvajal and Goldstein 1969, Severino and Verano 1980, Ivanov and Campbell 1998, this study). Records of species of Acanthobothrium in batoids of the family Arhynchobatidae from South America could be related to the high diversity of this family in some areas of the Southwestern Atlantic Ocean and Southeastern Pacific Ocean (Weigmann 2016). The further exploration of arhynchobatid batoids from Northwestern and Southwestern Pacific Ocean may potentially increase the number of described species of Acanthobothrium, considering the high diversity of that family in those areas (Weigmann 2016).

It is noteworthy that $A$. carolinae sp. n. is the first record of species of Acanthobothrium parasitising the genus Bathyraja (Ishiyama), even though this genus is the most diverse within the family Arhynchobatidae, with 49 species (Weigmann 2016). The lack of previous reports is probably related to the distribution of these batoids in deep waters, which makes their sampling more difficult. Still, future searching of species of Acanthobothrium in batoids 
of the genus Bathyraja may provide significant information on cestode diversity in the Argentine Sea, as this is the most diverse genus of rajiforms in that area, with 11 species (Froese and Pauly 2019).

The categorisation system of Ghoshroy and Caira (2001) is based on the combination of four features (total length, number of proglottids, number of testes and symmetry of the ovary) to classify species of Acanthobothri$u m$. This system has been very useful for the description of new species in such a diverse genus, through comparisons with those species belonging to the same category. However, Franzese and Ivanov (2018) observed intraspecific variability in ovarian symmetry when re-describing $A$. zapterycum Ostrowski de Núñez, 1971. This variability had not been considered by Ghoshroy and Caira (2001) when they classified A. zapterycum as belonging to category 2 . In fact, no variability in ovarian symmetry was reported for any of the species categorised by Ghoshroy and Caira (2001), Fyler and Caira (2006) and Zaragoza-Tapia et al. (2019), possibly because classifications were based on the original descriptions and not on reviews of the type material.

In the present study, we observed an intraspecific variability in ovarian symmetry both for $A$. carolinae sp. n. and $A$. domingae sp. n. As previously stated by Franzese and Ivanov (2018), such variation raises doubts about the validity of this feature for distinguishing among species. In this context, the categorisation system proposed by Ghoshroy and Caira (2001) should be used with caution, particularly when considering the paired categories 1 and 2, 3 and 4, 5 and 6, and 7 and 9, which differ from each other only in the symmetry of the ovary.

Fifty two species of Acanthobothrium have been observed with scanning electron microscopy to the moment, all of them showing a relatively homogeneous microthrix pattern (e.g., Fyler and Caira 2006, Reyda and Caira 2006, Fyler et al. 2009, Maleki et al. 2015, 2019). Essentially, filitriches cover most of the worm surface, while gladiate spinitriches are restricted to the cephalic peduncle, scolex proper, proximal bothridial surfaces and, in a few species, also to the distal bothridial surface (Caira and Zahner 2001, Fyler et al. 2009, Franzese and Ivanov 2018). The three Acanthobothrium species reported from rajiforms off Argentina generally follow that pattern. However, all three share a unique distribution of spinitriches on the scolex, with the gladiate spinitriches interrupted in a longitudinal band on the dorsal and ventral surfaces of the cephalic pe- duncle. To our knowledge, this feature was only found in these species.

Prior to 2018, the host species occurring off the coast of Argentina from which we collected A. domingae was considered to be Zearaja chilensis (Guichenot) (Belleggia et al. 2016), a species reported from Uruguay to northern Chile. Based on morphological and molecular data, Gabbanelli et al. (2018) proposed the resurrection of Z. brevicaudata for the specimens in the Southwestern Atlantic Ocean. Therefore, the distribution of $Z$. chilensis was restricted to the Pacific Ocean. More recently, Concha et al. (2019) proposed a new species, Dipturus lamillai Concha, Caira, Ebert et Pompert for specimens taken off Malvinas Islands, and synonymised Zearaja Whitley with Dipturus Rafinesque. As a consequence, Z. chilensis and Z. brevicaudata were transferred to Dipturus. Our findings on cestode fauna in D. bravicaudatus show that it is the host for a different species of Acanthobothrium than the one found in D. chilensis (i.e., A. domingae and Acanthobothrium annapinkiensis, respectively). This reinforces the notion that the species of Dipturus inhabiting the Southwestern Atlantic Ocean and the Southeastern Pacific Ocean are different.

Acknowledgements. Thanks are due to Juan M. Díaz de Astarloa, Ezequiel Mabragaña, Matías Delpiani and Martín Vázquez from Laboratorio de Biotaxonomía Morfológica y Molecular de Peces (Universidad Nacional de Mar del Plata- CONICET) for their help in the identification of hosts collected on board of the RV "Puerto Deseado". We would also like to thank Gustavo Chiaramonte, who made laboratory facilities at the Estación Hidrobiológica Quequén, Museo Argentino de Ciencias Naturales- CONICET available to us. Special thanks are due to Ariadna Battista from IBBEA (CONICET-UBA) for assistance with histological sections, to Carolina Tropea from IBBEA (CONICET-UBA) for revising the languague, and to Adriana Menoret from IBBEA (CONICET-UBA) for her support in many aspects of this research. Also special thanks to Tomáš Scholz, Editor of Folia Parasitologica, for his patience and good predisposition to attend all our queries. We also thank Consejo Nacional de Investigaciones Científicas y Técnicas (CONICET) for giving us the chance to work on board the Research Vessel "Puerto Deseado". This work has been funded by grants UBACyT 20020130100617BA (2014-2017) from Universidad de Buenos Aires (Argentina), PIP No. 11220150100705 from Consejo Nacional de Investigaciones Científicas y Técnicas (CONICET, Argentina) and PICT 20142358 (2015-2018) from Agencia Nacional de Promoción Científica y Tecnológica (Argentina) to VAI. This study was conducted under collecting permits No. 39 and No. 260 from Dirección Provincial de Pesca-Ministerio de Asuntos Agrarios de la Provincia de Buenos Aires, Argentina.

\section{REFERENCES}

Belleggia M., Andrada N., Paglieri S., Cortés F., MasSA A.M., Figueroa D.E., Bremec C. 2016: Trophic ecology of yellownose skate Zearaja chilensis, a top predator in the south-western Atlantic Ocean. J. Fish Biol. 88: 1070-1087.

Caira J.N., Jensen K., Barbeau E. (Eds.) 2019: Global Cestode Database. World Wide Web electronic publication. www.tapewormdb.uconn.edu, 03/2019.

Caira J.N., Jensen K., Ivanov V.A. 2017: Onchoproteocephalidea II. In: J.N. Caira and K. Jensen (Eds), Planetary Biodiversity
Inventory (2008-2017): Tapeworms from Vertebrate Bowels of the Earth. University of Kansas, Natural History Museum, Special Publication No. 25, Lawrence, pp. 279-304.

Caira J.N., Zahner S.D. 2001: Two new species of Acanthobothrium Beneden, 1849 (Tetraphyllidea: Onchobothriidae) from horn sharks in the Gulf of California, Mexico. Syst. Parasitol. 50: 219-229. 
Campbell R.A., Beveridge I. 2002: The genus Acanthobothrium (Cestoda: Tetraphyllidea: Onchobothriidae) parasitic in Australian elasmobranch fishes. Invertebr. Syst. 16: 237-344.

Carvajal J.G., Goldstein R.J. 1969: Acanthobothrium psammobati sp. n. (Cestoda: Tetraphyllidea: Onchobothriidae) from the skate, Psammobatis scobina (Chondrichthyes: Rajidae) from Chile. Zool. Anz. 182: 432-435.

Chervy L. 2009: Unified terminology for cestode microtriches: a proposal from the International Workshops on Cestode Systematics in 2002-2008. Folia Parasitol. 56: 199-230.

CLOPTON R.E. 2004: Standard nomenclature and metrics of plane shapes for use in gregarine taxonomy. Comp. Parasitol. 71: 130 140.

Concha F.J., Caira J.N., Ebert D.A., Pompert J.H.W. 2019: Redescription and taxonomic status of Dipturus chilensis (Guichenot, 1848), and description of Dipturus lamillai sp. nov. (Rajiformes: Rajidae), a new species of long-snout skate from the Falkland Islands. Zootaxa 4590: 501-524.

Franzese S., Ivanov V.A. 2018: Hyperapolytic species of Acanthobothrium (Cestoda: Onchoproteocephalidea) from batoids off Argentina. Parasitol. Int. 67: 431-443.

Froese R., Pauly D. (Eds.) 2019: FishBase. World Wide Web electronic publication, www.fishbase.org, 04/2019.

FyLER C.A. 2009: Systematics, biogeography and character evolution in the tapeworm genus Acanthobothrium van Beneden, 1850. Doctoral Dissertation. University of Connecticut, Connecticut, USA, $182 \mathrm{pp}$.

FyLER C.A. 2011: An extremely hyperapolytic Acanthobothrium species (Cestoda: Tetraphyllidea) from the Japanese wobbegong, Orectolobus japonicus (Elasmobranchii: Orectolobiformes) in Taiwan. Comp. Parasitol. 78: 4-14.

Fyler C.A., Caira J.N. 2006: Five new species of Acanthobothrium (Cestoda: Tetraphyllidea) from the freshwater whipray (Himantura chaophraya). J. Parasitol. 92: 105-125.

Fyler C.A., CAira J.N. 2010: Phylogenetic status of four new species of Acanthobothrium (Cestoda: Tetraphyllidea) parasitic on the wedgefish Rhynchobatus laevis (Elasmobranchii: Rhynchobatidae): implications for interpreting host associations. Invertebr. Syst. 24: 419-433.

Fyler C.A., Caira J.N., Jensen K. 2009: Five new species of Acanthobothrium (Cestoda: Tetraphyllidea) from an unusual species of Himantura (Rajiformes: Dasyatidae) from northern Australia. Folia Parasitol. 56: 107-128.

Gabbanelli V., Diaz de Astarloa J.M., González-Castro M., Vazquez D.M., Mabragaña E. 2018: Almost a century of oblivion: integrative taxonomy allows the resurrection of the longnose skate Zearaja brevicaudata (Marini, 1933) (Rajiformes; Rajidae). C. R. Biol. 341: 454-470.

Ghoshroy S., Caira J.N. 2001: Four new species of Acanthobothrium (Cestoda: Tetraphyllidea) from the whiptail stingray Dasyatis brevis from the Gulf of California, Mexico. J. Parasitol. 87: 354-372.

Goldstein R.J. 1964: Species of Acanthobothrium (Cestoda: Tetraphyllidea) from the Gulf of Mexico. J. Parasitol. 50: 656-661.
Ivanov V.A., Campbell R.A. 1998: A new species of Acanthobothrium van Beneden, 1849 (Cestoda: Tetraphyllidea) from $R i-$ oraja castelnaui (Chondrichthyes: Rajoidei) in coastal waters of Argentina. Syst. Parasitol. 40: 203-212.

Maleki L., Malek M., Palm H.W. 2015: Four new species of Acanthobothrium van Beneden, 1850 (Cestoda: Onchoproteocephalidea) from the guitarfish, Rhynchobatus cf. djiddensis (Elasmobranchii: Rhynchobatidae), from the Persian Gulf and Gulf of Oman. Folia Parasitol. 62: 1-15.

Maleki L., Malek M., Palm H.W. 2019: Five new species of Acanthobothrium (Cestoda: Onchoproteocephalidea) from the long-tailed butterfly ray, Gymnura cf. poecilura (Elasmobranchii: Gymnuridae), from the Persian Gulf and Gulf of Oman. Zootaxa 4609: 289-307.

Maleki L., Malek M., Rastgoo A. 2018: Acanthobothrium chabahariense $\mathrm{n}$. sp. (Cestoda: Onchoproteocephalidea) in the cowtail stingray Pastinachus cf. sephen (Myliobatiformes: Dasyatidae) from the Gulf of Oman, Iran. J. Genet. Resour. 4: 114-121.

Reyda F.B., Caira J.N. 2006: Five new species of Acanthobothrium (Cestoda: Tetraphyllidea) from Himantura uarnacoides (Myliobatiformes: Dasyatidae) in Malaysian Borneo. Comp. Parasitol. 73: 49-71.

Rodríguez-Ibarra E., Pulido-Flores G., ViolanteGonzÁlez J., Monks S. 2018: A new species of Acanthobothrium (Eucestoda: Onchobothriidae) in Aetobatus cf. narinari (Myliobatidae) from Campeche, México. Braz. J. Vet. Parasitol. 27: $67-74$.

Severino R., Verano R. 1980: Acanthobothrium lusarmientoi $\mathrm{n}$. sp. (Cestoda: Tetraphyllidea: Onchobothriidae). Psammobatis caudispina Hildebrand, 1941 (Chondrichtyes: Rajiidae) de Peru. Rev. Cienc. Univ. Nac. Mayor San Marcos 72: 21-27.

Tazerouti F., Kechemir-Issad N., Euzet L. 2009: Acanthobothrium minus $\mathrm{n}$. sp. (Tetraphyllidea: Onchobotriidae) parasite de Raja asterias (Elasmobranchii: Rajidae) en Méditerranée. Parasite 16: 203-207.

Vardo-Zalik A.M., Campbell R.A. 2011: Five new species of Acanthobothrium van Beneden, 1849 (Cestoda: Tetraphyllidea) in elasmobranchs from the northwest Atlantic and Gulf of Mexico with first records from smooth-hound sharks and guitarfish. Zootaxa 2838: 41-64.

Weigmann S. 2016: Annotated checklist of the living sharks, batoids and chimaeras (Chondrichthyes) of the world, with a focus on biogeographical diversity. J. Fish Biol. 88: 837-1037.

Zaragoza-Tapia F., Pulido-Flores G., Violante-González J., Monks S. 2019: Two new species of Acanthobothrium Blanchard, 1848 (Onchobothriidae) in Narcine entemedor Jordan \& Starks, 1895 (Narcinidae) from Acapulco, Guerrero, Mexico. ZooKeys 852: 1-21.

Zschoche M., Caira J.N., Fyler C.A. 2011: A new species of Acanthobothrium van Beneden, 1850 (Tetraphyllidea: Onchobothriidae) from Pastinachus atrus (Macleay) (Batoidea: Dasyatidae) in Australian waters, with a reassessment of the host associations of Acanthobothrium spp. parasitising Pastinachus spp. Syst. Parasitol. 78: 109-116.

Cite this article as: Franzese S. and Ivanov V.A. 2020: Two new species of Acanthobothrium (Cestoda: Onchoproteocephalidea) from rajiform batoids off Argentina. Folia Parasitol. 67: 016. 